Abstracta Iranica Abstracta Iranica

Revue bibliographique pour le domaine irano-aryen

Volume 28 | 2007

Comptes rendus des publications de 2005

\title{
"Temple, marzēah and Power at Elephantine ». Trans., 29, 2005, pp. 37-47.
}

\section{Astrid Nunn}

\section{(2) OpenEdition}

1 Journals

\section{Édition électronique}

URL : http://journals.openedition.org/abstractairanica/15252

DOI : 10.4000/abstractairanica. 15252

ISSN : 1961-960X

Éditeur :

CNRS (UMR 7528 Mondes iraniens et indiens), Éditions de l'IFRI

\section{Édition imprimée}

Date de publication : 15 mai 2007

ISSN : 0240-8910

\section{Référence électronique}

Astrid Nunn, « «Temple, marzēah and Power at Elephantine ». Trans., 29, 2005, pp. 37-47. », Abstracta Iranica [En ligne], Volume 28 | 2007, document 67, mis en ligne le 18 septembre 2007, consulté le 25 septembre 2020. URL : http://journals.openedition.org/abstractairanica/15252 ; DOI : https://doi.org/ $10.4000 / a b s t r a c t a i r a n i c a .15252$

Ce document a été généré automatiquement le 25 septembre 2020.

Tous droits réservés 


\section{«Temple, marzēah and Power at Elephantine ». Trans., 29, 2005,} pp. 37-47.

\section{Astrid Nunn}

1 Une garnison judéenne se trouvait à Éléphantine au V $\mathrm{V}^{\mathrm{e}}$ s. av. J.-C. Il y avait là, à sa disposition, le temple de Yahô, dont la fonction religieuse et cultuelle ne fait aucun doute. Il semble avoir également eu une fonction sociale. Selon la « liste de collectes » 128 Judéens d'Éléphantine donnaient deux sicles pour le temple de Yahô. Pourquoi cet argent était-il rassemblé? Une estimation de l'ensemble de la population juive d'Éléphantine basée sur le nombre d'unités militaires, montre que 128 ne représentent que l'élite de la population. L'argent aurait pu être donné pour le fonctionnement communal du temple. L'A. propose de lier «la liste de collectes» avec un texte évoquant le marzēah. Deux des trois noms cités dans le cadre du marzēah apparaissent également dans « la liste de collectes ». Ces deux textes indiquent qu'un petit groupe dirigeait les Juifs d'Éléphantine qui, même soumis au pouvoir perse, vivaient leur vie religieuse sans être coupés des autres communautés.

\section{INDEX}

Thèmes : 3.2.2. Pré-Achéménides et Achéménides 
AUTEURS

ASTRID NUNN

Université de Munich 